DOI: 10.20472/IAC.2017.034.016

\author{
INNOCENTS EDOUN \\ Tshwane University of Technology, South Africa \\ HEWS KGAPHOLA \\ TUT Business School, South Africa
}

\title{
THE EFFECT OF INTERNATIONAL TRADE ON EMERGING ECONOMIES: THE CASE OF INDIA
}

\begin{abstract}
:
Past and current studies indicate that, India is one of the fastest growing and most attractive economies in the world and has emerged as a desirable destination for Foreign Investment. Since 1991 India has been operating under strict policies which restricted the economy from an International trade, this drove more protectionism than open market trade. Indian government since 1991 introduced economic reform measures, to stimulate the economy. These reform measures in fiscal, reduction on the level of tariffs based on a large number of imports, exchange rate, the use of the exchange rate as the instrument for export promotion and trade policies. However, the reforms that were implemented in the Indian were not very different from the reforms undertaken by developing countries, the only alteration would be the swiftness with which they are implemented. India has one of the advantages which is the stability of its political climate. The current government and party that is in power have held the political landscape in place under control and this is providing the investor-friendly environment. India has gained influence within the global economy, this is demonstrated by India position in the international institutions like (G-8, G-20) and the free trade arrears with ASEAN, EU. This is also reflected by the by India's willingness to adopt international best practices in the production of the range of goods and services. India has attracted U\$195bn in FDI over the past 5 years. "India's GDP for 2013, valued at US\$ 1.9 trillion at current prices is the 10th largest in the world". The Indian government has a target of 8 per cent during the current Five Year Plan (2012-2017), for their economic growth, this is based on the demonstrated ability to sustain national economic growth."This paper will elaborate more on the rationale to explore trade in India. Economic theory and empirical evidence have clearly established the links between Trade, Productivity, and Economic growth. Countries that have large internal markets have also benefited by integrating themselves into the world economy, and thus opening up their economies like South Africa and India as one of the BRICS countries. India is projected to be the fastest-growing economy in the world over the next several decades. Trading with different countries respectively has made India what it is regarded as trading hub of today after China in the BRICS Countries.
\end{abstract}

\section{Keywords:}

India, foreign Investment, economic growth, economic theory, trade

JEL Classification: F30, A10, F10 


\section{1- INTRODUCTION}

Past and current studies indicate that, India is one of the fastest growing and most attractive economies in the world and has emerged as a desirable destination for Foreign Investment. Since 1991 India has been operating under strict policies which restricted the economy from an International trade, this drove more protectionism than open market trade. Indian government since 1991 introduced economic reform measures, to stimulate the economy. These reform measures in fiscal, reduction on the level of tariffs based on a large number of imports, exchange rate, the use of the exchange rate as the instrument for export promotion and trade policies. However, the reforms that were implemented in the Indian were not very different from the reforms undertaken by developing countries, the only alteration would be the swiftness with which they are implemented. India has one of the advantages which is the stability of its political climate. The current government and party that is in power have held the political landscape in place under control and this is providing the investor-friendly environment. India has gained influence within the global economy, this is demonstrated by India position in the international institutions like (G-8, G-20) and the free trade arrears with ASEAN, EU. This is also reflected by the by India's willingness to adopt international best practices in the production of the range of goods and services. India has attracted U\$195bn in FDI over the past 5 years. "India's GDP for 2013, valued at US\$1.9 trillion at current prices is the 10th largest in the world". The Indian government has a target of 8 per cent during the current Five Year Plan (2012-2017), for their economic growth, this is based on the demonstrated ability to sustain national economic growth. "India's government led by Prime Minister Narendra Modi is pro-growth and is considered business friendly. Modi's party, the Bharatiya Janata Party (BJP or Indian People's Party), BJP came to power in May 2014 winning a convincing majority of the $543-$ seat parliament in a general election with a voter turnout of $66.38 \%$."This paper will elaborate more on the rationale to explore trade in India. Economic theory and empirical evidence have clearly established the links between Trade, Productivity, and Economic growth. Countries that have large internal markets have also benefited by integrating themselves into the world economy, and thus opening up their economies like South Africa and India as one of the BRICS countries. India is projected to be the fastestgrowing economy in the world over the next several decades. Trading with different countries respectively has made India what it is regarded as trading hub of today after China in the BRICS Countries.

With the population estimated to 1.5 billion people and the world's third largest economy in purchasing power parity terms, India's recent domestic growth has been a significant achievement. It has been regarded as one of the developing countries in the BRICS structure. It is also becoming quite obvious that the balance of global economic power is moving away from developed countries to developing countries such as India and it's appropriate that it is one of the countries that is regarded as potent trading countries.

Since its independence in 1947 from the Britain coloniasm, a landmark agricultural revolution has transformed the nation from chronic dependence on grain imports into 
an agricultural powerhouse that is now a net exporter of food. Life expectancy has more than doubled, literacy rates have quadrupled, health conditions have improved, and a sizeable middle class has emerged. India is now home to globally recognized companies in pharmaceuticals and steel and information and space technologies, and enjoys a voice on the international stage that is more in keeping with its size and potential.

\section{Defining Trade}

According to Hill (2014:160), Trade is the act or process buying, selling, or exchanging commodities, at either wholesale or retail, within a country or between the countries. Hill (2014: 160) further explains that Free trade refers to a situation in which a government does not attempt to influence through quotas or duties what its citizens can buy from another country, or what they can produce and sell to another country.

Every country needs to deal with several foreign countries for trading, investment and other business activities. It is a fact, that this trend is becoming more and more visible with the globalisation gaining momentum. With India being a member of BRICS Countries, it is evident that doing trade with India as a country is one of the good and intergral move and that can be beneficial to business at large.

\section{Foreign Direct Investment}

According to Kishor Sharma (2000), Export growth in India has been much faster than GDP growth over the past few decades. Several factors appear to have contributed to this phenomenon including Foreign Direct Investment (FDI). According to Hill (2014:223) Foreign Direct Investment is a direct investment in business operations in a foreign countries.

Braunstein and Brenner (2007), further says that many economists and policy-makers treat foreign direct investment (FDI) as a premier agent of economic growth in developing countries.

Especially since the financial crises of the late 1990s, when short-term capital flows proved to be unreliable and destabilizing, governments have courted FDI as the international capital flow of choice. In adding up to directly raising investment, trade and consequent growth, FDI is often lauded for expanding employment opportunities, introducing technological and managerial know-how, and providing valuable access to highly competitive export markets.

Trading or doing business with India as one of the developing countries it is vital to take into considerations the following factors: 


\subsection{Tariff on Consumers and Producers}

According to Hill (2011) Tariffs are one of the seven trade instruments used by governments across the globe to intervene in international trade. Tariffs are used by governments to protect the local domestic producers against foreign producers or competitors. This protection is achieved by means of tax which is levied on imports or by raising the cost of imported goods from foreign countries. Lowering the tariffs increases trade volumes. Meanwhile without trade, domestic supply and demand in the two countries trading together will result in equilibrium prices whereby the consumers will suffer because of that.

\subsection{Effect on Producer}

Tariffs are seen to favour producers. Local domestic producers gain because of tariffs as it leads to high prices of the goods. Local producers further enjoy the protection against foreign competitors. Meanwhile, high tariffs are seen to address the rate of unemployment in home countries because the labour force is required for production. Kawahara (2013). Finally, tariff increases the government revenue. In India, tax levied on imports is $40 \%$ as compared to $30 \%$ which is levied on foreign companies investing in India, the strategy of the government on Foreign Direct Investment (FDI) is to addresses the issue of unemployment rate in the country.

\subsection{Reducing trade costs}

Trade costs are generally estimated to be a more significant obstacle to trade than policy barriers. In 2004, for example in India, aggregate expenditure on shipping only was three times higher than the aggregate tariff duty paid, Anderson and Van Wincoop (2004). consequently, any change in trade costs is likely to affect trade significantly. Technological innovation has had a major impact on trade costs. The introduction of containerization and jet engines has significantly reduced sea and air transport costs

\subsection{India Trade and innovation}

According to Anderson \& Van Wincoop (2004), Trade affects companies incentive to innovate through its effect on the size of the market in which a company operates as well as through its effect on competition, Technology transfers and Institutions. Most of companies spends more time on Research and Development to increase profits or to keep up with competition from other innovating companies. else being equal, the larger the market, the larger the company expected profits from innovation. By increasing the size of the market in which a company operates, trade provides companies with the better knowledge and understanding of doing business in India.

5. The following are the fundamental economic factors to consider when trading with India as a developing and a BRICS member in good standing: 


\subsection{Demographic change}

According to Anderson \& Van Wincoop (2004), The Indian's population is expected to reach 6.3 billion by 2030 and 9.3 billion by 2050 . Most of this will take place in certain part of the developing cities like New Delhi that are in the early stages of their demographic transition and which will see significant increases in the young workingage population of both sexes. They further states that in other developing cities and in most developed ones, the demographic transition is already in its most advanced stage. Fertility rates are low, resulting in an ageing population and in a shrinking labour force. In some of these cities, immigration is likely to be the main source of population growth in the future and will dominate the production of the country. Furthermore, Anderson \& Van Wincoop (2004) says, Education and urbanization are advancing everywhere in Indian cities more especially the Southern part of the country. The objective of this section is to show how these long-term demographic trends in the country such as India are likely to affect international trade patterns through their impact on comparative advantage as well as on the level and composition of import demand.

\subsection{Investment}

The accumulation of physical capital can affect the nature of international trade in a variety of ways. Greater public infrastructure investment can facilitate a country's participation in world markets by, for instance, reducing trade costs and hence increasing supply capacity. According to Kawahara (2013), Such investment in physical capital can therefore lead to the emergence of "new players" Or New business ventures in country's trade.

Investment in Roads, Ports and other Transport infrastructure can also strengthen regional trade, while investment in Information and Communications technology (ICT) infrastructure can enable a larger number of countries to participate in the ever expanding country trade in services. In an economy where factors of production, such as capital, cannot move across countries trading, investment must be financed by domestic resources. Cross country resource flows are, however, the current reality.

\subsection{Technology}

According to Cetindamar (2010), Technology is a Process, technique, or methodology embodied in a product design or in a manufacturing or service process which transforms inputs of labour, capital, information, material, and energy into outputs of greater value. Technological differences between countries are an important determinant of income levels and trade. Without technology in this era of living, trading will just be something that is unachievable.

Empirical research has shown that the accumulation of physical and human capital can only partially explain different income levels across countries, and different trade patterns. Easterly and Levine (2001). The residual is commonly attributed to 
technological differences between countries, whereby technology is defined as the information or knowledge required for production. Technological progress is undoubtedly the major factor explaining the fast growth in income and will always be in the 21st century more especially in developing countries like India and South Africa.

\subsection{Transportation costs}

According to Behar and Venables ( 2010), The cost of transporting goods from producers to users affects the volume, direction and pattern of trade. It determines where the line between tradable and non-tradable goods is drawn and shapes which companies are able to participate in trade and how they will organize their production internationally.

The cost of transportation is in turn influenced by a wide range of fundamental determinants. These include the geographical features of countries i.e. India and South Africa, the quantity and quality of the physical infrastructure that support transportation services, the procedures and formalities used to control the movement of goods from one country to another, the extent of competition in the transportation sector, the pace of technological innovation in the sector and the cost of fuel. The characteristics of the products being shipped also affect transportation costs. Transportation when intending doing business in India should be looked into for the main purpose of good delivery of products to be transported.

\subsection{Institutions}

This section studies the relationship between International trade and the institutional framework of the country.

\subsubsection{Political institutions}

Political institutions shape economic interactions in two ways: Firstly, they impose constraints on government activities; Secondly, they influence the set of economic institutions that societies adopt. The economic literature has tended to focus in particular, on the impact of the form of government and political borders on international trade. Form of government, defined by the extent of accountability, Legitimacy, Transparency and Choice in a political system, may impact trade indirectly through economic development or directly by altering policy-maker's incentives to set trade policy. Furthermore, Political borders impact trade flows directly by increasing trade costs and indirectly by fragmenting the international political system in the countries concerned. 


\subsubsection{Economic Institutions}

According to Behar and Venables (2010), Economic institutions especially the quality of regulations and the rule of law in India provide a critical structure for economic interaction with other countries intending doing business with the country. Clearly, Stable and Enforceable rules are fundamental to international trade relations as they limit uncertainty by creating a framework within which economic exchange takes place.

\section{Conclusions}

Evidently so, India is one of the top three (3) developing countries where every country associates itself with the country to trade with. Some of the factors that contributes in ensuring that trade takes place smoothly so, need to be adhered to. Furthermore considering doing business with the country aspects such as Technology, Political stability or instability and above all the Economic factors need to be considered at all times.

It is important to take note that India is growing its Economy with a pace where opportunities are also available for foreign investors for the purpose of trading and growing the economy of the country.

\section{REFERENCES}

ANDERSON, JAMES E. \& Van WINCOOP, E., 2004., The American Economy: Review., Volume NO. 1:170-192(23): Journal article: American Economic Association.

BRAUNSTEIN, E., BRENNER M., 2007. Foreign Direct Investment AND

Gendered Wages In Urban China., Journal article: Feminist Economics 13(34).

BEHAR A. \& VENABLES J. 2011., Transport Costs and International Trade., University Of Oxford and CEPR

CETINDAMAR, D. PHALL, R. \& PROBERT, D. 2010. Technology Management. UK: Palgrave MacMillan

EASTERLY W.,\& LIVINE R., 2001., It's Not Factor Accumulation: Stylized Facts and Growth Models., The World Economic Review., Journal Article: Vol.15, No.2 177-219

KAWAHARA, S. 2013. Welfare and market-access effects of piecemeal tariff reforms on environmentally preferable products. The Journal of International Trade \& Economic Development, 23 ( 6), 796814.

SHARMA K., 2000. Export Growth In India: Has FDI PLAYED A ROLE?., Charles Sturt University: JOURNAL ARTICLE., P 106., Australia 